\title{
COOPERATION OF HIGHER \\ EDUCATION INSTITUTIONS \\ WITH ENVIRONMENT. \\ SELECTED ISSUES ON MEASUREMENT \\ OF HEIS' THIRD STREAM ACTIVITIES
}

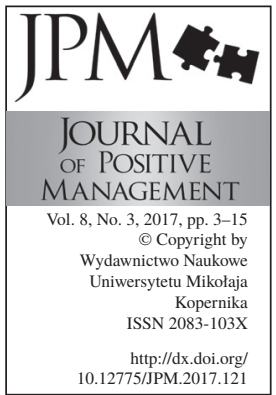

\author{
Agnieszka Piotrowska-Piątek \\ Kielce University of Technology, Poland \\ e-mail: apiotrowska@tu.kielce
}

\begin{abstract}
Purpose: This article discusses cooperation of Polish higher education institutions (HEIs) with their environment and offers a way of measuring these activities. The concept and scope of the third stream are discussed and selected model and indicators of measuring HEIs' activities in this field are presented. The Author suggests Indicator of Cooperation with Environment (ICE) in order to measure levels of HEIs' interaction with the world around them.

Methodology: The article draws on relevant literature both from Poland and abroad. In order to verify the proposed ICE indicator empirically, a survey was carried out among 100 heads of Polish HEIs. The results of the survey were analysed by using tools of descriptive statistics, and presented according to HEI types.

Findings: The results show correlation between the ICE level and HEI type. The highest level of ICE is observed in public academic HEIs, which makes them stand out as a group as against the other types of HEIs. A significantly lower level of ICE is identified in the case of state vocational HEIs and private HEIs, which makes them a homogeneous group in terms of ICE.

Originality: As can be seen in the literature, the issue of how to measure HEIs' third stream is rarely raised at a conceptual level and, consequently, in empirical research. The ICE indicator proposed in this article is based on simple indicators which are easy to operationalise and which reflect activities involving teaching, research, academic entrepreneurship as well as HEI management. Validation has confirmed that ICE is effective in achieving the intended measurement goals.

Keywords: higher education institutions (HEIs), third mission, cooperation of HEIs with environment, index
\end{abstract}

Paper type: Research paper

\section{Introduction}

Undoubtedly, cooperation of higher education institutions (HEIs) with their environment, often defined as HEIs' third stream, is one of the most frequent issues raised while discussing the HEI's teaching and management model (cf.: 
COOPERATION OF HIGHER EDUCATION

Agnieszka Piotrowska-Piątek
Leja, 2003; Kwiek, 2015). For HEIs to meet the challenges of modern societies and their economies, it seems necessary to be open to the world around them by adjusting their teaching programmes to the labour market needs, developing research relevant to the needs of society and economy, implementing flexible organisational structures, and inspiring academic entrepreneurship.

This article discusses the issue of Polish HEIs' cooperation with their environment in the light of how to measure such activities: the topic relatively rarely raised in empirical research. Theoretical considerations concerning the concept and scope of the HEIs' third stream will provide the background to presenting the proposed model and indicators to measure HEIs' activity in this field. The article draws on the relevant literature both from Poland and abroad. The Author suggests Indicator of Cooperation with Environment (ICE) in order to measure levels of HEIs' cooperation with their environment. The proposed indicator has been empirically verified in the Author's research, the results of which are presented according to HEI types.

\section{Concept of HEIs' third stream}

The concept of the third mission/third stream of HEIs highlights the importance of HEIs' cooperation with the world around them (education and research being the first and second missions respectively). Unlike the two fundamental missions, ie education and research, the third mission did not constitute the core of academic mission at the time HEIs were established.

While considering the evolution of an idea of a university and its mission, Koj points out that in the modern world the two fundamental missions of a university clearly are not sufficient as HEIs' interaction with the local community and participation in solving current social and economic problems is becoming increasingly important (2013). Likewise, Sutz, as early as two decades ago, drew attention to HEIs' transformation, and pointed out that, apart from their two traditional roles, ie teaching students and conducting research, HEIs had another, increasingly important role: creating mutual relations with the world around them (1997). At present, the concept of the third mission is considered intrinsically important and deserving special conditions and means to put in practice (MolasGallart, Salter et al., 2002).

As can be seen in the relevant literature, the term of a third mission is used to define various activities, deriving from education and research, that HEIs address to local communities or society as a whole. This conclusion can be illustrated by a brief outline of some relevant findings.

Kożuch and Przygodzka point out that the third mission reflects new expectations towards HEIs and involves a widely perceived cooperation with HEIs' external stakeholders (2011). The range of this cooperation is discussed by Leja, who sees the third mission as development of various forms of lifelong 
learning addressed to children, young people, adults who want to extend their qualifications or develop their interests as well as those who intend to acquire a new profession, regardless of age and formal education. Leja also sees the third mission in the economic perspective: as transfer and commercialisation of technology as well as in the social perspective: as contribution to culture (2013).

The importance of innovative and entrepreneurial dimensions of activities undertaken within the third mission are often emphasised in the literature (cf. Dyrkowski and Popek, 2013). In Conclusions on the Modernisation of Higher Education, the Council of the European Union mentions the following third stream activities: innovation, knowledge-sharing, community engagement, lifelong learning and relevance to regional and local development (2011).

There are also relatively narrow approaches which associate the third stream with research commercialisation only (e.g. George et al., 2005; Buczek and Modrzyński, 2015). Such approaches, which can be defined as a technocratic perspective of the third mission, are represented by researchers involved in academic incubators of entrepreneurship or technology transfer centres.

The concept of the third mission is close to the concept of the social mission of HEIs. This term is used by Błażejowski to define HEIs' activity in their interaction with the social environment. Admittedly, elements of such a mission are present in HEIs' educational and research activity. However, it is believed that the social mission also includes intrinsically social aspects that are becoming increasingly essential for modern societies to function. This category includes culture-forming and formative roles of HEIs, which encompasses integrating local community and mediation in solving social problems. This mission involves creating and promoting standards of social attitudes and behaviour, as well as promoting scientific discoveries and lifelong learning (2013).

The English language literature often refers to the third mission as the third stream, emphasising the importance of revenue gained beyond the public support system and from tuition fees paid by students. Zomer and Benneworth regard the third mission as a response to the demands of government, industry and other social stakeholders of HEIs (2011).

To conclude the definition perspectives presented above, and based on the Author's research (2015), the Author defines the third mission HEIs as all the activities addressed to regional and local communities in terms of education, conducting research and sharing its findings, as well as HEIs' activities resulting from possessing financial and physical resources. This terminology perspective has informed the studies presented in this article.

\section{Measurement of HEIs' activity in the third stream}

In order to create models and indicators to measure HEIs's activity within the third stream, it is necessary to get an insight into the ways HEIs contribute to the 
COOPERATION OF HIGHER EDUCATION

Agnieszka Piotrowska-Piątek society. Molas-Gallart, Salter, Patel, Scott and Duran (2002) propose a holistic conceptualisation of such measurement. Their model has been created to address the needs of management policy of HEIs' system in the UK, however, given a universal character of HEIs' activity, it can serve as a useful tool to develop the concept of measuring such activity in the Polish higher education system.

The model proposed by Molas-Gallart, Salter, Patel, Scott and Duran is based on a distinction between HEIs' potential and capabilities and their activity. Drawing on the example of British research universities, they point out that universities have capabilities in two fundamental areas: knowledge capabilities (knowledge stock) and facilities potential (e.g. buildings, laboratories, libraries, IT centres). Using their capabilities, universities are active in three areas: teaching, research and communicating the results of their work. Molas-Gallart et al. point out that these three sets of activities should be considered third stream when they involve and address non-academic community (2002).

Molas-Gallart et al. also point out that there are significant differences between universities as well as between disciplines in which they make an impact on the society and economy. This diversity makes it difficult to develop a universal model measuring the third stream that could be applied to all types of HEIs. What is more, some third stream activities are conducted beyond the formal system or at a departmental level (as well as at the level of other organisational units of HEIs - the Author's comment), and the top management level (of universities or relevant governmental agencies - the Author's comment) may not be informed of such activities. That is why such informal and invisible activities are difficult to observe and measure (Molas-Gallart et al., 2002).

Molas-Gallart et al. suggest that the model of measuring third stream activity should comprise the following twelve sets of indicators (2002):

- technology commercialisation indicators, e.g. number of patent applications, patents awarded, royalty incomes,

- indicators of entrepreneurial activity, e.g. the number of spin-offs created in the last five years, profits from spin-offs, funds provide to support start-ups,

- indicators of advisory work, e.g. the number of invitations to nonacademic conferences, the number of invitations to meetings of advisory committees of non-academic organisations,

- indicators of commercialisation and use of university facilities, e.g. the number of events organised by a university for public benefit, income from hiring facilities such as conference rooms, the number of days spent by external visitors using university laboratories (free of charge),

- indicators of research contracts with non-academic clients, e.g. value of contracts, the number of research contracts signed by universities with external organisations, 
- indicators of non-academic collaboration in academic research, e.g. the number of publications authored by non-academics, the number of non-academic organisations involved in research projects funded by foundations or research centres, value of grants, value of contributions provided by non-academic organisations to such projects,

- indicators of flow of academic staff, scientists and technicians, e.g. the number of employees from non-academic organisations or the number of academic staff taking temporary positions in external, non-academic organisations,

- indicators of student placements, e.g. the number of students participating in sandwich courses and internships organised by universities,

- indicators of active alignment of teaching to economic and societal needs, e.g. the number of graduates who found a job within 18 months after graduation, the number of postgraduate students directly sponsored by universities, the percentage of graduates and employers highly satisfied with the knowledge and skills acquired by graduates through the university course,

- indicators of learning activities, e.g. income generated by universities from teaching and other services offered to industry, community members, administration, the number of organisations participating in such offers,

- indicators of social networking, e.g. the number of non-academic professional conferences attended by university staff members,

- indicators of non-academic dissemination, e.g. the number of appearances by academic staff members in regional, national and international radio and TV programmes, the number of times universities and their staff are mentioned in the press in the context of their teaching and research activities.

Molas-Gallart et al. emphasise the variability of cost and time needed to access data (various places of information generated) necessary to develop the indicators suggested. They also identify the following critical points connected with the process of monitoring HEIs' activities within the third stream (2002):

- the contribution of universities to society is complex, non-linear and selfreinforcing,

- universities differ between each other in terms of the third mission activity,

- the type of discipline heavily influences the way universities interact with the rest of society,

- commercialisation indicators alone are not enough to estimate the third stream activity as commercialisation activity is heavily concentrated in particular disciplines, thus in particular types of schools. What is more, 
COOPERATION

OF HIGHER

EDUCATION

Agnieszka Piotrowska-Piątek commercialisation indicators alone are a relatively shallow reflection of overall economic and social benefits offered by universities,

- a variety of indicators should be used: each indicator taken by itself will be incomplete and open to questioning,

- existing indicators are not sufficient: the wide range of third stream activities can only be reflected if new approaches are used to give full justice to a diverse character of universities' interactions with the rest of society,

- indicators must be clear, consistent and comparable.

Molas-Gallart et al. point out that a final aggregate result should be reached by combining the results for all the twelve categories. Given the differences between the school types, they propose the following three options of measuring university activity (2002):

- the set menu option, whereby all groups of indicators and all universities are treated equally and each university is assessed against all the indicators in the same way. The main strength of this option is its simplicity and clarity in comparing universities;

- balancing weighting option, whereby individual universities can weight, within certain limits, the importance of categories for them. The main strength of this option is the fact that it allows a university to choose their priorities in the third stream and to measure the activity accordingly;

- type of university option, whereby three or four types of universities are distinguished and university is allowed to choose the type by which to be measured, e.g. research-intensive, teaching-intensive or communityfocused types.

\section{Measuring the third stream of HEIs' activity in Poland}

The framework discussed above can serve as a basis for observing Polish HEIs' third stream activity. However, the choice of categories and indicators themselves must be modified. Based on the assumption that HEIs' activities are defined by their capabilities resulting from their resources, i.e. knowledge (embodied in human resources, results of teaching and research) and facilities (such as laboratories, libraries, software) and are focused on realising their two fundamental missions, i.e. teaching and research, it is possible to identify the following analytical areas/categories:

- academic entrepreneurship,

- commercialisation of research, development work and know-how,

- advisory services for external organisations,

- alignment of teaching to labour market needs,

- teaching offer to groups other than university students,

- making university facilities available to external users, 
- participation in collaboration networks,

- participation of external stakeholders in management structures of HEIs.

The interdependence of these categories is presented in Figure 1.

Understandably, the borders between the presented areas are not fully closed, e.g. overlapping of 'advisory services' and 'participation in collaboration networks'. The areas encompass types of activities legitimised by the Act of Higher Education and reflected by HEIs' practices. Table 1 shows indicators that, given the specifity of the Polish higher education system, can be applied to monitoring

THIRD MISSION

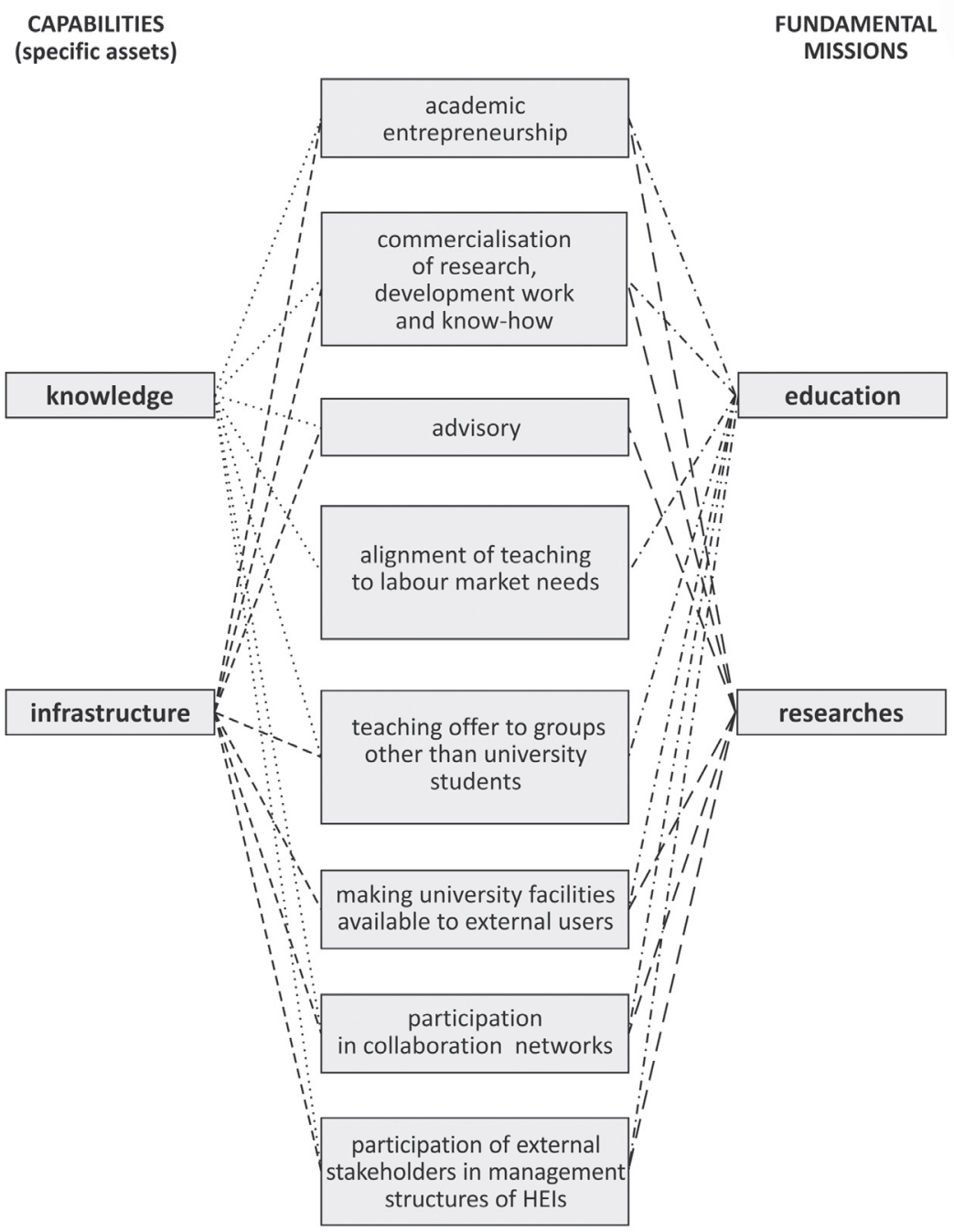

Figure 1. Categories of measuring Polish HEIs' third stream activity

Source: the Author's. 
COOPERATION

OF HIGHER

EDUCATION

Agnieszka Piotrowska-Piątek
Table 1. Indicators to measure Polish HEIs' third stream Source: the Author's
Polish HEIs' third stream activity. Admittedly, it is possible to identify much more indicators. However, the indicators proposed here are based on practical grounds, are easy to operationalise, and the data necessary to analyse them are accessible from internal information systems of HEIs (including internal reporting on quality of teaching and commercialisation of research and development work) and from the National System of Monitoring Alumni Careers (ELA). At an aggregated level (according to types of schools), some indicators are available in published results of periodical (thus enabling long-term analysis) surveys carried out by the Central Statistical Office of Poland and the Polish Business and Innovation Centres Association.

\begin{tabular}{|c|c|}
\hline Area of analysis & Examples of indicators \\
\hline \multirow[b]{2}{*}{ Academic entrepreneurship } & No. of academic incubators (preincubators) of entrepreneurship \\
\hline & $\begin{array}{l}\text { No. of spin-offs set up by university staff/ undergraduate and } \\
\text { postgraduate students of a university }\end{array}$ \\
\hline \multirow{7}{*}{$\begin{array}{l}\text { Commercialisation of } \\
\text { research, development work } \\
\text { and know-how }\end{array}$} & $\begin{array}{l}\text { Technology transfer centres or other units responsible for techno- } \\
\text { logy transfer }\end{array}$ \\
\hline & $\begin{array}{l}\text { No. of trademark, industrial design, utility model and invention } \\
\text { applications to The Polish National Patent Office }\end{array}$ \\
\hline & No. of patents awarded from The Polish Patent Office \\
\hline & No. of patents awarded from foreign patent offices. \\
\hline & Incomes from licence royalties \\
\hline & $\begin{array}{l}\text { Incomes from research, including sales of research and develop- } \\
\text { ment services }\end{array}$ \\
\hline & Incomes from business activity \\
\hline \multirow{2}{*}{ Advisory services } & No. of expert opinions offered to external organisations \\
\hline & No. of consultations offered to external organisations \\
\hline \multirow{6}{*}{$\begin{array}{l}\text { Alignment of teaching to } \\
\text { labour market needs }\end{array}$} & $\begin{array}{l}\text { System of monitoring labour market needs in terms of realised } \\
\text { teaching programmes within internal procedures of enhancement } \\
\text { quality of teaching }\end{array}$ \\
\hline & $\begin{array}{l}\text { Percentage of courses of a practical profile run with the support } \\
\text { of professional practitioners }\end{array}$ \\
\hline & $\begin{array}{l}\text { No./percentage of academic staff members who possess practical } \\
\text { experience }\end{array}$ \\
\hline & $\begin{array}{l}\text { Percentage of graduates who found employment with twelve } \\
\text { months after graduation }\end{array}$ \\
\hline & Average time from graduation to starting the first job \\
\hline & $\begin{array}{l}\text { No./percentage of dissertations and } \mathrm{PhD} \text { theses written 'on } \\
\text { request' from or with involvement of businesses or labour market } \\
\text { institutions }\end{array}$ \\
\hline
\end{tabular}




\begin{tabular}{|c|c|}
\hline Area of analysis & Examples of indicators \\
\hline \multirow{3}{*}{$\begin{array}{l}\text { Teaching offer to groups } \\
\text { other than university students }\end{array}$} & $\begin{array}{l}\text { Teaching offer addressed to local groups other than university } \\
\text { students }\end{array}$ \\
\hline & $\begin{array}{l}\text { No. of long-term and periodical educational programmes/projects } \\
\text { addressed to groups other than university students }\end{array}$ \\
\hline & $\begin{array}{l}\text { No./percentage of university staff members involved in prepa- } \\
\text { ring and running educational programmes/projects addressed to } \\
\text { groups other than university students }\end{array}$ \\
\hline $\begin{array}{l}\text { Making university facilities } \\
\text { available to external users }\end{array}$ & $\begin{array}{l}\text { No. of events/projects organised by external organisations or ad- } \\
\text { dressed to external organisations, with using university facilities } \\
\text { free of charge }\end{array}$ \\
\hline \multirow{2}{*}{$\begin{array}{l}\text { Participation in collaboration } \\
\text { networks }\end{array}$} & $\begin{array}{l}\text { No. of networking organisations and initiatives with participation } \\
\text { of university staff }\end{array}$ \\
\hline & $\begin{array}{l}\text { No./percentage of university staff members representing universi- } \\
\text { ty in networking organisations and initiatives }\end{array}$ \\
\hline \multirow{3}{*}{$\begin{array}{l}\text { Participation of external } \\
\text { stakeholders in management } \\
\text { structures of HEIs }\end{array}$} & $\begin{array}{l}\text { HEIs' structures include a council or a body performing coun- } \\
\text { cil's tasks }\end{array}$ \\
\hline & $\begin{array}{l}\text { Type of powers/authority of a council or a body performing } \\
\text { council's tasks }\end{array}$ \\
\hline & $\begin{array}{l}\text { Structure/categories of stakeholders of a council or a body per- } \\
\text { forming council tasks }\end{array}$ \\
\hline \multicolumn{2}{|c|}{$\begin{array}{l}\text { The indicators proposed above are of a tangible character, which is measurable } \\
\text { d allows observation over time and space (between HEIs similar to each other } \\
\text { terms of e.g. size or teaching profile). However, it is impossible to present } \\
\text { e whole range of HEIs' third stream activities if only tangible indicators are } \\
\text { ed. Polish HEIs vary in terms of their aspirations, missions and development } \\
\text { ategies, which results from diversity of HEIs' founders (state and private } \\
\text { hools), teaching profiles, range of research, specifity of a region they operate in } \\
\text { well as regional institutional relations. Thus the measurement and assessment } \\
\text { HEIs' third stream activity needs to take account of indicators of at least a few } \\
\text { the identified areas, including soft indicators of a descriptive character, e.g. } \\
\text { pe of council's powers. } \\
\text { It is worth remembering that not all the activities are monitored either } \\
\text { ternally or externally: HEIs perform some activities but there is no mechanism } \\
\text { measuring them. Likewise, not all of these activities give tangible results that } \\
\text { ird stream activities should involve time series which take account of specifity of } \\
\text { given measurement area. This is especially important when assessing activities } \\
\text { research, development work and know-how. }\end{array}$} \\
\hline
\end{tabular}

Making university facilities

No. of events/projects organised by external organisations or adfree of charge

No. of networking organisations and initiatives with participation No./percentage of university staff members representing university in networking organisations and initiatives

HEIs' structures include a council or a body performing councouncil's tasks

Structure/categories of stakeholders of a council or a body performing council tasks

The indicators proposed above are of a tangible character, which is measurable and allows observation over time and space (between HEIs similar to each other in terms of e.g. size or teaching profile). However, it is impossible to present the whole range of HEIs' third stream activities if only tangible indicators are used. Polish HEIs vary in terms of their aspirations, missions and development strategies, which results from diversity of HEIs' founders (state and private schools), teaching profiles, range of research, specifity of a region they operate in as well as regional institutional relations. Thus the measurement and assessment of HEIs' third stream activity needs to take account of indicators of at least a few of the identified areas, including soft indicators of a descriptive character, e.g.

It is worth remembering that not all the activities are monitored either internally or externally: HEIs perform some activities but there is no mechanism of measuring them. Likewise, not all of these activities give tangible results that can be visible directly in a short-time perspective. Generally, assessment of HEIs' a given measurement area. This is especially important when assessing activities whose outcome can be observed in long-term perspective, such commercialisation fesearch, development work and know-how. 
COOPERATION

OF HIGHER

EDUCATION

Agnieszka Piotrowska-Piątek

Table 2. Areas and indicators of measuring HEIs' third mission activities, as used in ICE development

Source: The Author's.
Based on the presented above framework of measuring Polish HEIs' third stream activity, the Author has developed Indicator of Cooperation with Environment (ICE), which has been empirically verified by the results of the Author's study.

\section{Methodology, assumptions and organisation of study}

As Babbie points out, indicators, as a type of complex measure, are used in quantitative studies due to a paucity of clear and explicit indicators for variables in social sciences. What is more, analysis of individual information usually provides a very general indicator of a given phenomenon (2004). Development of an indicator includes the following stages:

- selection of individual indicators (questions),

- examination of empirical interdependence between individual indicators,

- establishing index score,

- index external validation.

In order to measure HEIs' third stream activity, five areas of the areas presented above (Table 1) have been selected. Individual indicators have been chosen for each area (Table 2).

\begin{tabular}{ll}
\hline Area of analysis & Individual indicators* \\
\hline Academic entrepreneurship & $\begin{array}{l}\text { Existence of academic incubators (preincubators) of } \\
\text { entrepreneurship in HEI structures. }\end{array}$ \\
\hline $\begin{array}{l}\text { Commercialisation of research, } \\
\text { development work and know-how }\end{array}$ & $\begin{array}{l}\text { Existence of technology transfer centres or other units } \\
\text { responsible for technology transfer in HEI structures. }\end{array}$ \\
\hline $\begin{array}{l}\text { Alignment of teaching to labour } \\
\text { market needs }\end{array}$ & $\begin{array}{l}\text { System of monitoring labour market needs in terms of } \\
\text { realised teaching programmes within internal procedures } \\
\text { of enhancement of quality of teaching. }\end{array}$ \\
\hline $\begin{array}{l}\text { Teaching offer to groups other than } \\
\text { university students }\end{array}$ & $\begin{array}{l}\text { Teaching offer addressed to local groups other than uni- } \\
\text { versity students. }\end{array}$ \\
\hline $\begin{array}{l}\text { Participation of external stakeholders } \\
\text { in management structures of HEIs }\end{array}$ & $\begin{array}{l}\text { HEIs' structures include a council or a body performing } \\
\text { council's tasks. }\end{array}$ \\
\hline
\end{tabular}

* Nominal dichotomous scale has been used to measure indicators.

In accordance with the presented above development stages, selection of individual indicators should be followed by examination of interdependence between them. While a properly constructed index must show empirically verified interdependence between individual indicators/questions, this interdependence should not be too strong as this would mean the situation of one indicator being replicated by another, which would mean that including both of them contributes nothing new to the analysis (Babbie, 2004). 
Individual indicators have been assigned the same weight (1). The value of ICE has been obtained by aggregating values of individual indicators, which were 0 or 1 . Therefore, the theoretical value of ICE ranges from 0 to 5 points.

To verify the proposed index, a primary study has been conducted [1]. The study was conducted in the form of an individual questionnaire sent to those in charge of HEIs. All the HEIs supervised by the Minister of Science and Higher Education were included in the study, based on the list of active state and private HEIs (N: 377). The study was conducted from January to February 2015, and the final questionnaire return reached 100 replies, which makes this study not complete, despite its original intention. However, taking into account that $50 \%$ of state academic HEIs, $50 \%$ of state vocational HEIs, and almost $20 \%$ of private HEIs responded to the questionnaire, we may assume that this makes a good representation of the set to analyse. There is no way, post factum, to assess the randomness of the sample. Similarly, due to the fact that the subject is researched to a very little extent, it is hardly possible to directly relate our results to studies by other authors.

The results obtained have been analysed by tools of descriptive statistics tools of STATISTICA 13.1 package.

\section{Findings}

The Pearson correlation coefficient has been used to study the correlation between individual indicators of ICE. There was a positive, statistically significant correlation between the indicators [2]. The bivariate correlations obtained were clear or substantial; one pair of indicators showed had a significant correlation. As can be seen, the choice of indicators used to build ICE has been successful.

The mean value of ICE was $3.1(\mathrm{SD}=1.04)$, with the median of 3.0 and the modal value of 3.0. ICE distribution corresponds to the normal distribution. The results obtained show a variability of ICE levels according to types of schools [3]. For public academic higher education institutions, the results variability ranges from 2 to 5 points, in the case of state vocational schools from 0 to 4 , and for private schools from 1 to 5 . According to one-way analysis of variance (ANOVA), fulfilling the assumption of its homogeneity, the highest level of ICE can be attributed to public academic higher education institutions (3.74 on average), which makes this type of schools a significant group as compared to the other types of schools (according to Scheffe test). A considerably lower level of ICE has been obtained for state vocational schools (2.83 on average) and private schools (2.80 on average). These schools form a homogenous group in terms of ICE.

Validation was the final stage of empirical verification of the indicator. Of all the methods of validation available, external validation has been chosen, using a question included in the questionnaire but not used in the index. In one of the questions, HEIs' heads were asked to divide 10 points among three areas concerning their school's mission and strategy: teaching, research and the third 
COOPERATION OF HIGHER EDUCATION

Agnieszka Piotrowska-Piątek stream (the more points allocated, the bigger perceived importance of the area). In this way, the interdependence between ICE level and distribution of the answers to the question was analysed using Pearson's correlation. The coefficient obtained: 0.205 points at positive, clear and statistically significant correlation [4]. This means that the indicator proposed here achieves measurement goals, thus it is able to assess the level of HEIs' third mission activity.

\section{Summary}

In recent years, it has been emphasised that the third stream activities play an important role in public policies of the higher education system (Kwiek, 2013). It seems that the range and intensity of such activities will be increasing, and the activity in knowledge commercialisation and academic entrepreneurship, today characteristic of big and strong state schools (which is confirmed by the results presented in this article) will be gradually developed by the other types of HEIs, which mainly have been associated with their teaching mission so far. That is why systematic observation and measurement of third stream activities are essential both to HEI authorities and, at an aggregate level, to governmental institutions responsible for public policies in higher education.

As has been seen in the review of the literature presented in this article, this issue is rarely attempted at a conceptual level and, consequently, in empirical studies. One of the rare models and indicators of the third stream measurement is represented by the framework proposed by Molas-Gallart et al. They point out that a holistic approach is required to measure the third stream because this activity involves a wide range of HEIs' interaction with various external stakeholders and it cannot be narrowed down to commercialisation of research only (2012).

The Author has proposed Indicator of Cooperation with Environment (ICE), a novel construct to measure Polish HEIs' third stream activity. This indicator is based on simple elements, easy to operationalise and reflecting activities of teaching, research, academic entrepreneurship as well as managing HEIs. As has been shown here, the level of third stream activities is clearly differentiated according to types of HEIs.

The areas and indicators of Polish HEIs' third stream activity proposed in this article should be treated as a contribution to conceptual and empirical research on managing HEIs as well as an invitation to a wider discussion on this important issue.

\section{Notes}

[1] The study was wider in scope than that presented in this article.

[2] $\mathrm{p}<0.01$.

[3] $\mathrm{p}<0.05$.

[4] $\mathrm{p}<0.05$. 


\section{References}

COOPERATION

OF HIGHER

EDUCATION

Błażejowski, J. (2013), „Misja i posłannictwo polskich szkół wyższych na progu XXI wieku", in: Woźnicki, J. (Ed.), Misja i służebność uniwersytetu w XXI wieku, Wydawnictwo Instytutu Wiedzy i Fundacji Rektorów Polskich, Warszawa, pp. 21-24.

Buczek, J., Modrzyński, P. (2015), The third mission of Polish universities: Theory and practice, 2015 PRADEC Conference Proceedings, Vol. 3, No. 1, pp. 86-97.

Dyrtkowski, K., Popek, M. (2013), „Uwagi o przedsiębiorczości uczelni w modelu uniwersytetu III generacji”, in: Burawski, D. (Ed.), Uniwersytet Trzeciej Generacji. Stan i perspektywy rozwoju, Poznań, pp. 181-190.

George, G., Jain, S., Maltarich, M.A. (2005), Academics or Entrepreneurs? Entrepreneurial Identity and Invention Disclosure Behavior of University Scientists, available at: http://dx.doi.org/10.2139/ssrn.799277 (accessed 27 April 2017).

European Union, Council conclusions on the modernisation of higher education, Official Journal of European Union, 2011/C 372/09.

Kożuch, B., Przygodzka, R. (2011), „Zmiany zachowań organizacyjnych pod wpływem oczekiwań interesariuszy uczelni akademickich”, in: Wawak, T. (Ed.), Wyzwania zarządzania jakościa w szkołach wyższych, Wydawnictwo Uniwersytetu Jagiellońskiego, Kraków, pp. 49-63.

Kwiek, M. (2015), Uniwersytet $w$ dobie przemian, Wydawnictwo Naukowe PWN, Warszawa.

Kwiek, M. (2012), „The Growing Complexity of the Academic Enterprise in Europe: A Panoramic View", in: Kwiek M., Kurkiewicz A. (Eds.), The Modernisation of European Universities. Cross-National Academic Perspectives, Peter Lang, Frankfurt am Main, pp. 27-60.

Leja, K. (2013), Zarządzanie uczelnią. Koncepcje i współczesne wyzwania, WoltersKluwer, Warszawa.

Molas-Gallart, J., Salter, A., Patel, P., Scott, A., Duran, X. (2002), Measuring Third Stream Activities. Final Report to the Russell Group of Universities, SPRU, University of Sussex.

Piotrowska-Piątek, A., (2015), „Aktywność szkół wyższych na rzecz społeczności lokalnych - dyskusja wokół pojęcia trzeciej misji”, Optimum. Studia Ekonomiczne, 6, pp. 99-109.

Sutz, J. (1997), „The New Role of the University in The Productive Sector” in: Etzkowitz, H., Leydesdorff, L. (Eds.), Universities and the Global Knowledge Economy. A Triple Helix of University - Industry-Government Relations, Pinter, London and Washington, pp. 11-20.

Zomer, A., Benneworth, P. (2011), „The Rise of the University`s Third Mission”, in: Enders, J., de Boer, H., Westerheijden, D. (Eds.), Reform of Higher Education in Europe, Sense Publishers, Rotterdam - Boston-Taipei, pp. 81-102.
Agnieszka Piotrowska-Piątek 